\title{
New information and communication technologies in agriculture - factors, drivers and application possibilities
}

\author{
Róbert Szilágyi ${ }^{1}$
}

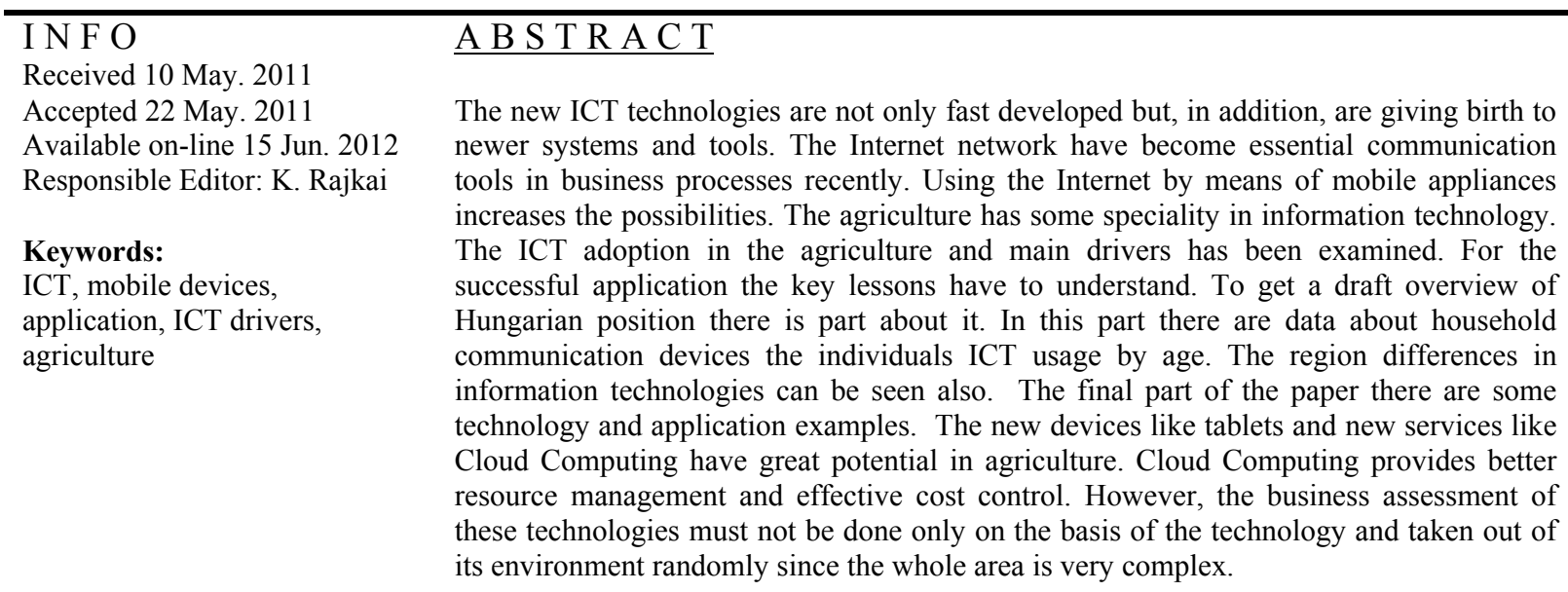

\section{Introduction}

The development of information technology has had a considerable influence on the agriculture of highly industrialised nations as well. There have emerged a number of new industry-specific technologies and applications over the past few years, including the ever-widening agricultural application of mobile communications devices and technologies. Further considerable improvement is expected in the use of the PDA (Personal Digital Assistant), the personal digital assistant and mobile computers (Handheld Computers) recently "renamed" Tablets as well as other mobile devices. Providing high broadband and mobile Internet access for every individual, especially for those living in rural areas (e-Rural), is among the first priorities of the European Union's research and development programme for Information Society Technologies (IST). According to researchdevelopmental and application trends, as well as forecasts and expectations, these technologies and services are to become widely applied tools in enhancing business innovations and supporting business management. The focus of this research was those Internet applications based on mobile devices and the assessment of their effects on agriculture. Due to the fact that the development of applications and user applications require wide-ranging condition and effect systems, the investigation of several condition and effect mechanisms and research tasks were carried out.

\subsection{The aim of the research}

The subject of this paper to answer what is the up to date ICT drivers and condition in the field of agriculture. The other subject is to draft the possible social and "digital gap" condition in the agriculture. In this paper, the ICT is taken as a possible management support tool, and I am looking for the answer of what factors and drivers are important in the agriculture. The following issues are examined here:

- what are the drivers of ICT in agriculture,

- what are the key lessons related to ICT in agriculture,

- what is the possible ICT condition (devices, services) in Hungary,

\footnotetext{
${ }^{1}$ Róbert Szilágyi

University of Debrecen

szilagyir@agr.unideb.hu
} 
- what trends can be observed in the mobile devices.

The aim of this research is as the ICT means a management support in the agriculture, and the new ICT solutions can be observed in the agriculture.

\subsection{The research method}

The examination of the subject is interdisciplinary. It has social and scientific references, so a complex approach was needed. The man research method was the analytical way, several analytical methods and approaches were selected. The data collection was relied on the available Hungarian related reports from the Hungarian Central Statistical Office, and the international data from Statistical Office of the European Communities, and the OECD. I am managed to process the ICT market reports and the international scientific works.

\section{Background}

\subsection{ICT adoption in the agriculture}

The information and communication technologies (ICTs) in the extension services and rural development projects takes an important role. The ICT usable for long term (for example electronic education for rural areas) and as well as short term (for example local market price and weather information) cases. The ICT can be used for help to collect and share the existing human capital. The usage of mobile phones can improve the private and the public information share. The mobile technology can provide better agricultural information services at lower cost and higher quality. (Dethier and Effenberger, 2012) The introduction of mobile phones has increased the efficiency of local markets in Niger, reduced the price 10-16\%. (Aker, 2010).

The properly implemented extension and other services can deliver the requested information for a farmers and helps them to adopt a new technology profitalibly. The possiblity to access new market, and the weather information is also important for producers. For example in India soy farmers used an Internet kiosk for agricultural price information and as a market channel, the cultivated area increased and resulted higher returns. (Goyal, 2010)

\subsection{Drivers of ICT in agriculture}

Actually there are five main drivers of the use of ICT in agriculture (World Bank, 2011):

- Low-cost and pervasive connectivity The Internet and the mobile coverage increased which resulted decreased costs and increased competition.

- Adaptable and more affordable tools The adaptable and more affordable technologies and devices has also increased the ICT's relevance to smallholder agriculture. Innovation has reduced the price of phones, laptops, scientific instruments, and software. Mobile applications are also becoming more useable for isolated communities (and of course the whole community). The existing technology (for example SMS) can provide mobile banking, market price alert, extended transaction possibilities (for example selling). The previously highly costed geospatial information is also becoming easier and cheaper (or free) to access and use.

- Advances in data storage and exchange The increased data storage capacity and the ability to access and share data remotely have improved the use of ICT in agriculture. The possiblity to share knowledge and exchange data have created opportunities to involve more stakeholders in agricultural research. The capacity of hard drives have continued to rise, making cheaper to store data. The cloud computing offers shared computing resources through the Internet.

- Innovative business models and partnerships The private sector became more interested in use of ICTs because their profit potential is clear. The public sector maintains great interest in ICT as providing better public services in agriculture (for example agricultural extension services). Private companies that have invested in technology and applications are often interested in working with the public sector to provide their products and services to smallholders. New forms of business incubation and knowledge brokering are also contributing to ICT in agriculture. Incubators identify investors and other suitable partners, including 
technical experts. Knowledge brokering means a case, when enterprise provides information for a fee (for example market price, weather information.

- Democratization of information, the open access movement, and social media ICTs is also contributing to agriculture and rural development more broadly. High amount of previously hardly accessible information are becoming visible, publicly accessible. Many governments and organizations are aiming to make data publicly available. The expansion of open access software also enables to share knowledge with each other. Social media (for example Facebook) is not only useable for entertainment, also greatly useable for knowledge sharing and collaboration even in agriculture. The sharing information and motivating collective action are the two key features of agriculture development. The crowdsourcing, in which scientists, governments, and development organizations request feedback from farmers and consumers through devices like mobile phones, is also facilitating agriculture development. Farmers can use SMS to send local agricultural information to the researchers.

\subsection{The key lessons related to ICT in agriculture}

The following key lessons are important for the successful ICT adaptation (World Bank, 2011):

- Concentrate on the demand, not on the technology It is important to begin any ICT development in agriculture by focusing on the farmer needs (for example better market information, better Internet access and application). The new technologies in any project require the farmers active contribution from the start.

- Use appropriate technologies Sometimes the newest ICT not the best possible solution, maybe the mixture of several existing technologies is better. The more complex technology require more training and qualified users. It is necessary to research and understand local information and communication practices, and the existing ICT background.

- Focus on affordable access and use, not ownership In agriculture the accessibility and useable technology are preferred. The reduced cost of ICT result the affordability and accessibility increased value. The use of the technology should be monitored to find it's economic means.

- Be aware of differential impacts, including gender and social differences in access and use The wrong use of ICT can worsen the economic, social, and political inequalities. For example in the rural area of Africa, the women have disadvantages in accessing information and communication technologies and services. Social access is the another weak point. For the whole agricultural economy is important to do not restrict poor producers for the use of up to date ICT, but the technologies itself does not guarantee full participation by all social groups.

- Create an enabling environment for innovation in infrastructure investment, business models, services, and applications The effective design and transparent implementation of policies and regulations for ICT infrastructure, tools, and services is key to enabling ICT development. ICT in agriculture require a strong, but flexible, regulatory environment; it is required for the private sector to make investments.

- Develop sustainable business and investment models through partnerships Public and private partnerships are essential to the long-term viability of ICT in agriculture. The public sector in developing countries may need guidance in providing technological services. The private investment in public service is often requested. For the success technical experts with experience in various subsectors; information technology teams, multi-level policy makers; and of course farmers and farmers' organizations are needed.

- Promote leadership and find champions ICT interventions require leadership. The champions are needed to push projects forward in the development agenda and make them visible and interesting to the stakeholders (farmers, businesses, and others). These leaders must operate at the national level. They must also operate at local levels, modeling the effective use of a technology and building farmers' trust in ICT. 


\section{The ICT in Hungary}

This data was relied on the available Hungarian Central Statistical Office ICT report (KSH, 2011).

There are some kind of computer devices (desktop PC, laptop, handheld) in the two-thirds of Hungarian households. There are desktop PC-s in the 59\% and laptop in the $26 \%$ of the households. In Hungary the Internet is available in $60 \%$ of the households. Figure 1.

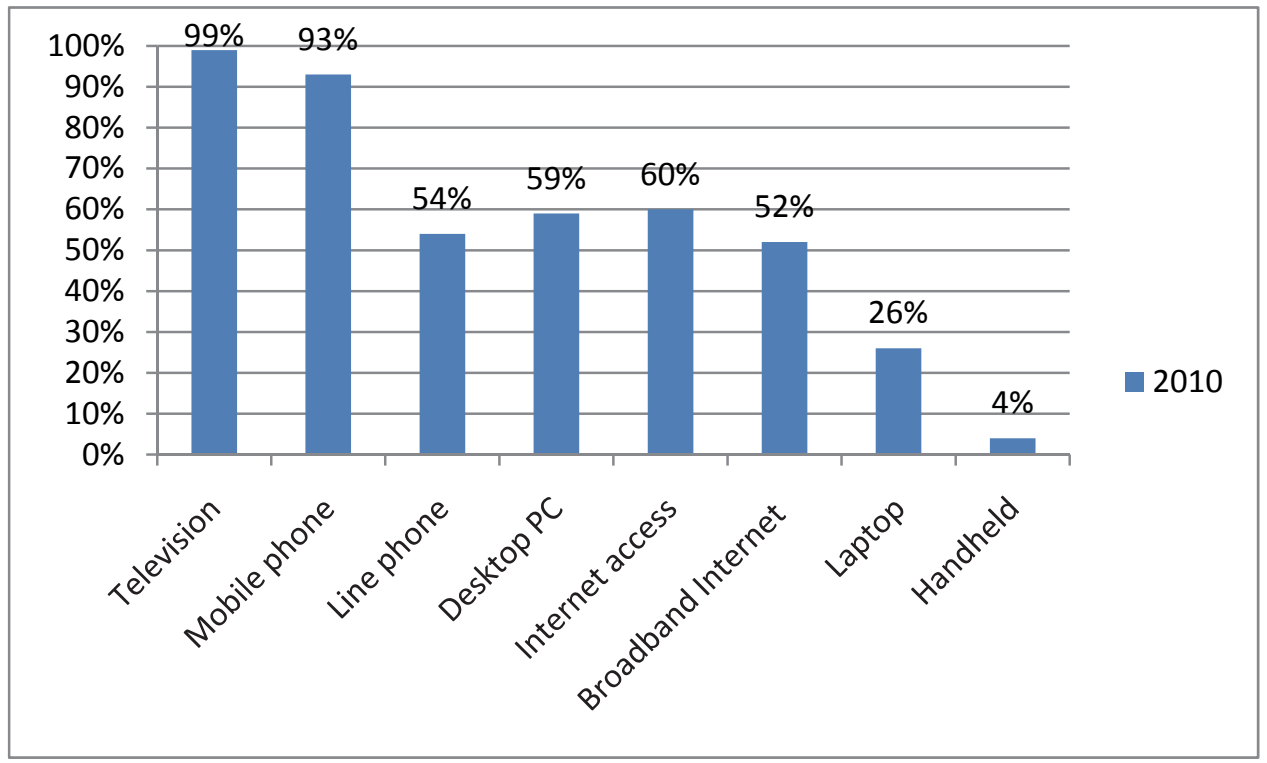

Figure 1. The Hungarian households ICT device proportion (KSH, 2011)

The Internet penetration is increased by $5,4 \%$ from 2009 to 2010 , but the previous year the increase rate was $6,7 \%$, so the rate is slowed a bit. There is similar rate in the European Union. The most of household Internet connection are cable, broadband mobile and ADSL.

\section{The ICT usage of the individuals}

More than $90 \%$ of the Hungarian population use mobile phone. Only the older than 55 years use less mobile (88\%) than the average (92\%). More than two-thirds $(69 \%)$ of the older than 65 years use mobile. Figure 2 .

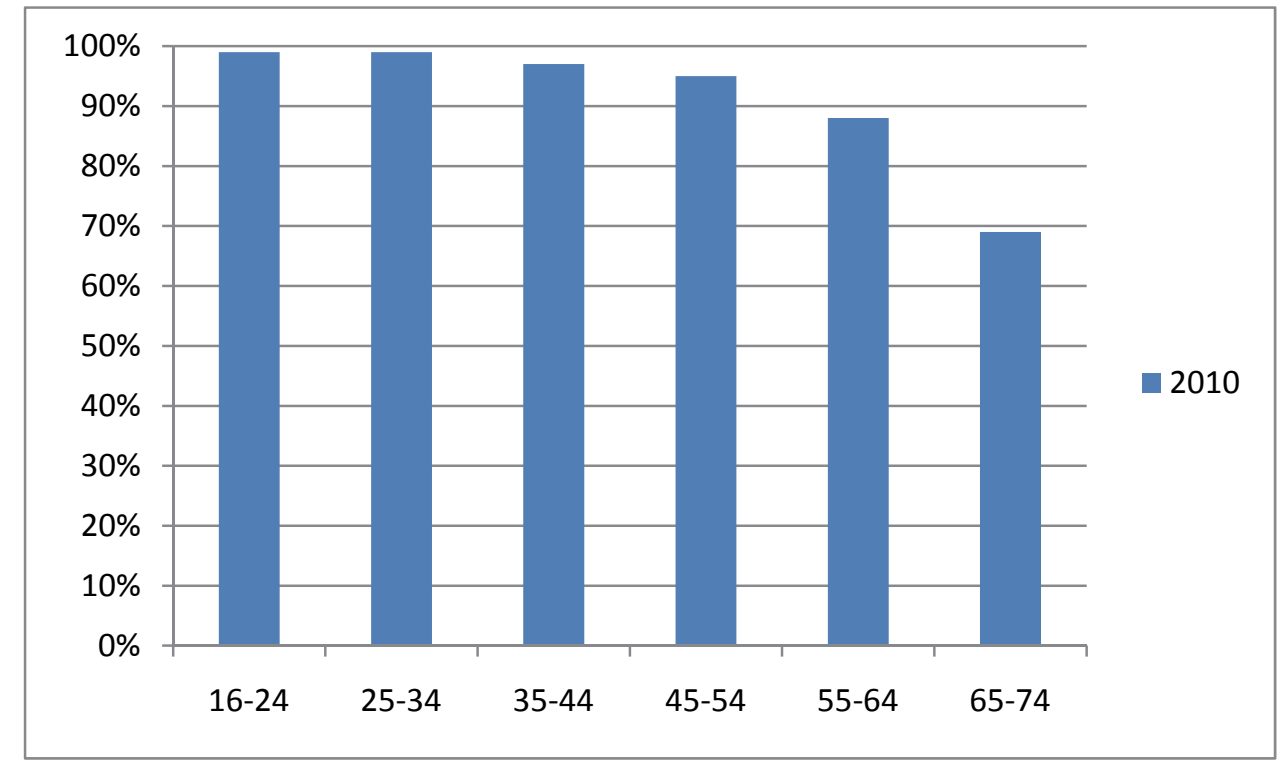

Figure 2. The Hungarian individuals mobile usage rate (KSH, 2011) 
In $201070 \%$ of the population used computer ever. This rate is $2 \%$ higher than a year before. Figure 3.

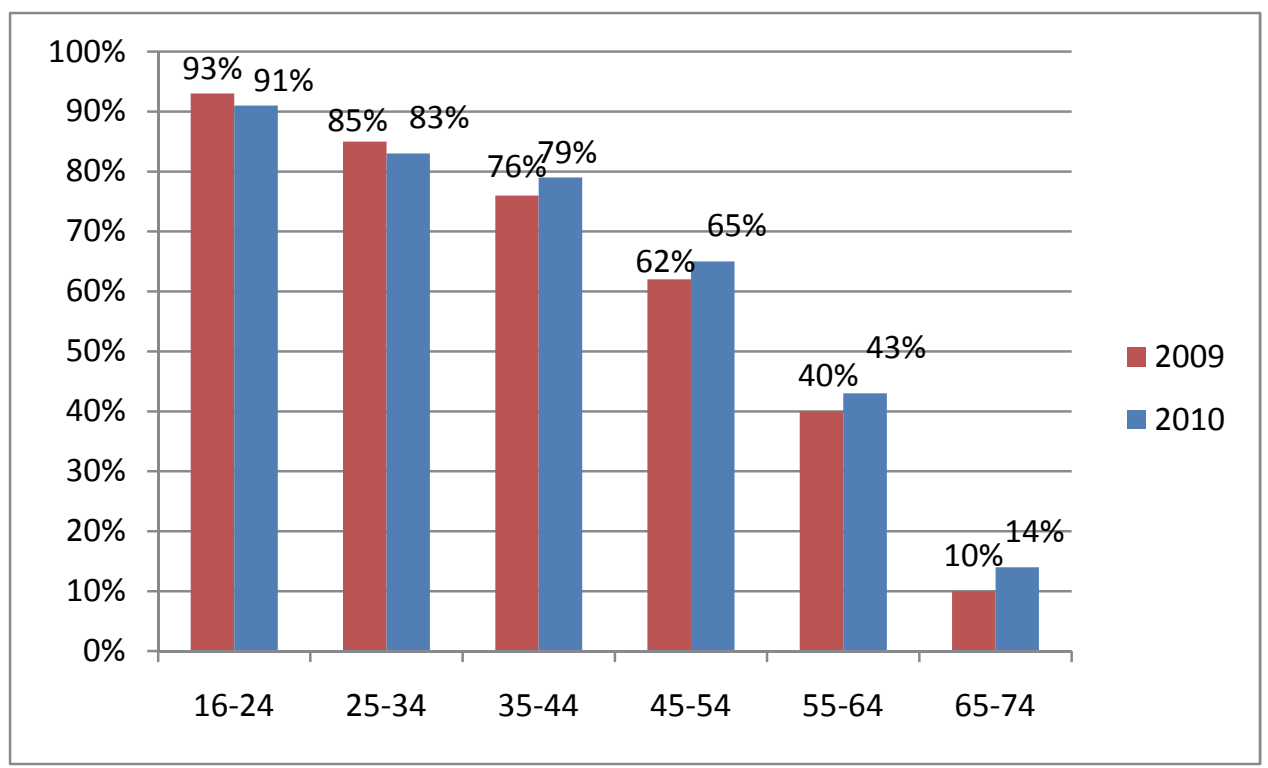

Figure 3. The Hungarian individuals who used computer (KSH, 2011)

In $201042 \%$ of the elementary educated, $89 \%$ of the higher educated used computer. The difference of them is decreased from 2009 to 2010. The rate among the secondary educated is closer to the higher educated computer usage $(78 \%, 89 \%)$. Figure 4 . The figure shows that the ICT usage is highly related to the level of personal education.

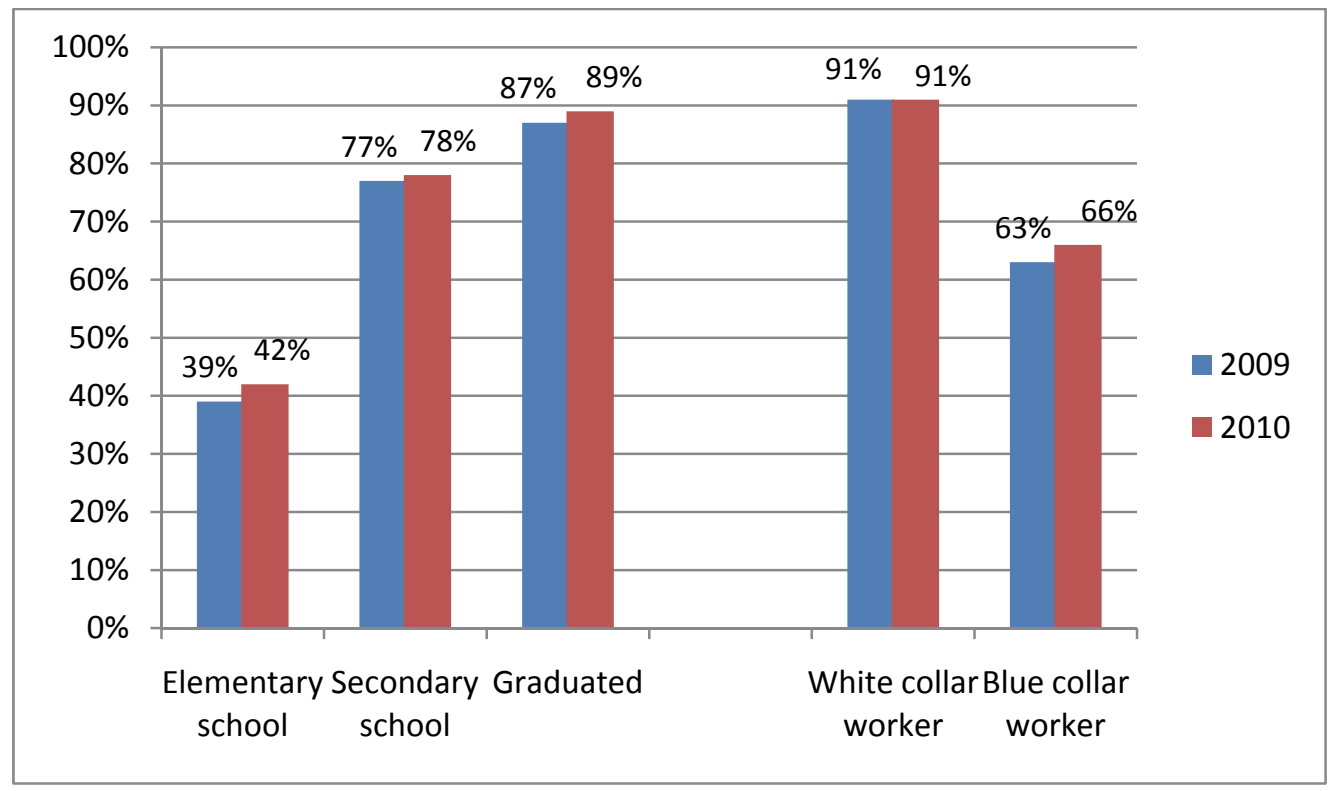

Figure 4. The computer users divided by education and working (KSH, 2011)

From 2009 to 2010 the computer users rate is fixed on $91 \%$ at white collar workers, but the blue collar workers rate increased 3\% (from 63\% to 66\%). The difference of the two kind of workers is decreased, but still high.

\section{The regional difference on ICT}

The regions difference on ICT can be seen on Table 1. The rank number is counted by the mobile phone, computer, Internet and broadband Internet access. The first in the list is Central 
Hungary, the second is Central Transdanubia, the third is Western Transdanubia. The Northern Hungary and Northern Great Plain are the last on the list.

Table 1. The Hungarian regions rank in ICT (KSH, 2011)

\begin{tabular}{|l|c|c|c|c|c|c|c|}
\hline & $\begin{array}{l}\text { Northern } \\
\text { Hungary }\end{array}$ & $\begin{array}{l}\text { Northern } \\
\text { Great Plain }\end{array}$ & $\begin{array}{l}\text { Southern } \\
\text { Great Plain }\end{array}$ & $\begin{array}{l}\text { Central } \\
\text { Hungary }\end{array}$ & $\begin{array}{l}\text { Central } \\
\text { Transdanubia }\end{array}$ & $\begin{array}{l}\text { Western } \\
\text { Transdanubia }\end{array}$ & $\begin{array}{l}\text { Southern } \\
\text { Transdanubia }\end{array}$ \\
\hline Mobile phone & 7 & 6 & 4 & 2 & 1 & 3 & 5 \\
\hline Computer & 6 & 7 & 5 & 1 & 3 & 2 & 4 \\
\hline Internet access & 5 & 7 & 4 & 1 & 2 & 3 & 6 \\
\hline $\begin{array}{l}\text { Broadband } \\
\text { Internet }\end{array}$ & 4 & 7 & 5 & 1 & 2 & 3 & 6 \\
\hline
\end{tabular}

If we count the number of agricultural worker, the list is the following Table 2.:

Table 2. The Hungarian regions rank by agricultural workers (KSH, 2012)

\begin{tabular}{|l|c|c|}
\hline Region name & Rate of agricultural worker & Rank \\
\hline Northern Hungary & $0,87 \%$ & 7 \\
\hline Northern Great Plain & $5,43 \%$ & 4 \\
\hline Southern Great Plain & $6,56 \%$ & 2 \\
\hline Central Hungary & $3,60 \%$ & 6 \\
\hline Central Transdanubia & $3,76 \%$ & 5 \\
\hline Western Transdanubia & $5,47 \%$ & 3 \\
\hline Southern Transdanubia & $6,65 \%$ & 1 \\
\hline
\end{tabular}

In those region where the rate of agricultural worker is relatively high (except Central Hungary) the ICT usage is lower.

Table 3. Region's Internet subscribers data (TEIR, 2012)

\begin{tabular}{|l|c|c|c|}
\hline & $\begin{array}{c}\text { Number of Internet } \\
\text { subscribers }\end{array}$ & \multicolumn{2}{|c|}{ Internet subscribers / Population } \\
\hline Name of the region & Rank & Ratio & Rank \\
\hline Southern Great Plain & 4 & $28,20 \%$ & 7 \\
\hline Southern Transdanubia & 7 & $30,25 \%$ & 4 \\
\hline Northern Great Plain & 2 & $28,94 \%$ & 6 \\
\hline Northern Hungary & 5 & $29,93 \%$ & 5 \\
\hline Central Transdanubia & 3 & $37,06 \%$ & 1 \\
\hline Central Hungary & 1 & $41,17 \%$ & 3 \\
\hline Western Transdanubia & 6 & $35,64 \%$ & \\
\hline
\end{tabular}

It is quite interesting to examine the regions Internet subscribers number shown by Table 3 . It is not surprise that Central Hungary has the highest subscriber number. The Southern Transdanubia and Western Transdanubia have the lowest subscribers. If we divide the subscribers number with the region's population number the rank of the regions change. Central Hungary still the first, but Southern and Norhtern Great Plain are the last in the list.

\section{The ICT development stage in the Hungarian agriculture}

An Hungarian research paper examined the Hungarian economic sectors ICT development stage (Sasvari, 2011). In the four cluster model the 'Agriculture, hunting and forestry' (along with the 'Construction', 'Hotels and restaurants' and 'Health and social work' economic sectors) got into the relative underdeveloped cluster 1.1. In the cluster 1.1 the average of the potential indicators to electronic presence, interaction/dialogue, transaction and electronic markets was the lowest in the four clusters. In the cluster 1.1. the usage of ICT devices less frequently than the national average. 


\section{New technology possibilities}

Certainly education, training and e-services play a very important role for ICT adoption by Agriculture and related areas (Herdon and Lengyel, 2008). The easy access of the information, knowledge and e-services is a key factor in agricultural.

ICT evolution is well advancing Moore's Law prediction of computer performance indexes. Indeed, these technologies are not only fast developed but, are giving birth to newer ones. These innovations of ICT are not only regenerating traditional sciences, like Agriculture. (Sideridis et al., 2010)

To refer to a few examples of these innovations affecting Agriculture and Environmental Sciences: Cloud Computing provides equality in resources management and exploitability. Parallel Computing (Campbell et al., 2010) brings exponentially increased core processing to low-end computers facilitating the use of huge computer power by small agricultural research units.

The use of cloud computing is getting more and more popular in agriculture also (Hori, et al., 2010). The GPS (Global Positioning System) and the 3G (Third Generation Network) are also useable in this case. There are two important part in knowledge management 1. Data storage, 2. Data analysis. The five universal values of cloud computing are the following:

- Reduction of initial costs,

- Allocation of resources on demand without limit,

- Maintenance and upgrades performed in the back-end,

- Easy rapid development including collaboration with other system in the cloud,

- More possibilities for global service development.

The Japanese researchers also propose a platform which is contain in three layers: SaaS layer (Software as a Service), PaaS layer (Platform as a Service), IaaS layer (Infrastructure as a Service) (Hori et al., 2010)

Greece researchers developed a system called the FARMA platform, the main aim of which is the storage and management of information on various categories of animals (e.g., sheep, cattle and pigs) (Voulodimos et al., 2010). The data collection is based on RFID tags and the information can be accessed with mobile devices. The three main subsystems that constitute the system are the central database, the local database and the mobile RFID subsystem. The mobile RFID subsystem comprises a mobile device (a PDA, UMPC or a laptop) and a portable RFID reader/writer attached to the mobile device. During the experimental period, animals responded well to the RFID tags. With the help of this system, more up to date information is collected. One possible enhancement of the platform is the GPS (some mobile devices are indeed already equipped with it), so that individual animals can be located.

Researchers highlight several ideas about the mobile internet in the field of agricultural egovernment (Ntaliani et al., 2010). They say that the existing web services have been adopted for implementing the e-government service as a cost effective and technical interoperable solution, by providing open sources.

Mobile farm equipment featuring different sensors is able to collect a large amount of data while working (Steinberger et al., 2009). Automated process-data acquisition can be the basis for information-steered agricultural production. Unfortunately, the use of these data is restricted by hardware and software compatibility, different data formats, the lack of a concept for reusing data and the amount of data. Using tools for automated treatment and storage, mobile farm equipment becomes an important source of knowledge for information-steered plant production.

Current and exact data are important on a farm. The on-farm sensor networks provide remote, realtime monitoring of important farming operations. The network is based on a 900Mhz network. The power supply consists of solar panels (which are unusable in cloudy weather conditions) (Pierce and Elliott, 2008).

Interworking between WLAN and UMTS will be a possible solution for the better anywhere, anytime Internet access. The transmission of data within WLAN-UMTS interworking system has 
several problem. The Mobile IP approach is possible way to interwork the heterogeneous network. (Soungalo et al., 2012)

In Australia to increase the efficiency of irrigation researchers developed an SMS communication based irrigation Decision Support System. Using the SMS as communication channel the main idea was to reduce the inappropriate information for the farmers.

All farmers received messages daily for the entire growing season. Although some of the farmers never sent back any data most of them found the system useful. Finally proved that the input data may be collected from irrigators via SMS so it can be used as a very cheap bi-directional communication channel. (Car et al., 2012)

\subsection{New trends in the field of mobile communication}

Mobile broadband services are becoming increasingly popular in the OECD area. New devices like smartphones already represent significant share of mobilephones in many countries. Mobile broadband is among the areas where growing revenues are expected. The WiMAX based 4G and LTE (Long-Term Evolution) technologies deployment begun.

Mobile access is the primary communication access path in the OECD area. The number of mobile subscriptions still increasing, the growth rate has slowed. Most of world growth in mobile subscription now comes from developing countries.

The new devices such as smartphones and tablets changed the business model because the growth of the application number. The market size of these applications is starting to be comparable with traditional television counterparts. (OECD, 2011)

\section{Conclusion}

Communication technologies and broadband Internet are increasingly perceived as a critical factor in social and economic development. They provide their connectivity for a range of innovative applications in areas like smart energy, electronic health services, e-government, and of course in the agriculture. Focusing on ITC the key drivers and the main factors of it there are special applications and requirements in this area, and sometimes the social factors are more important than technology. Giving a brief overview about the Hungarian ICT position and the differences in personal usage and regions some new applications like cloud computing, interworking between WLAN and UMTS network, using the SMS as communication channel were discussed. Finally listed some of the new trends in the mobile communication. As summary we can establish that the new information and communication technologies are play an important role in the agricultural area, too.

\section{References}

Aker, J.C., 2010. Information from markets near and far: mobile phones and agricultural markets in Niger. American Economic Journal: Applied Economics 2, 46-59.

Anderson, G. T., C. V. Renard, L. M. Strein, and E. C. Cayo. 1998. A new technique for rapid deployment of rollover protective structures. Applied Eng. in Agric. 23(2): 34-42.

Car N.J, Christen E. W., Hornbuckle J.W., Moore G.A., (2012): Using a mobile phone Short Messaging Service (SMS) for irrigation scheduling in Australia - Farmers' participation and utility evaluation, Computers and Electronics in Agriculture No. 84 (2012) 132-143 pp.

Dethier, J.-J., Effenberger, A., Agriculture and development: A brief review of the literature. Econ. Syst. (2012), doi:10.1016/j.ecosys.2011.09.003

Goyal, A., 2010. Information, direct access to farmers, and rural market performance in Central India. In: Policy Research Working Paper 5315, World Bank, Washington, DC.

Herdon M., Lengyel P. (2008): E-Learning course development in Moodle. Journal of EcoAgroTurism. Transilvania University of Brasov. ISSN 1841-642X. 336-340 p.p.

Hori M., Kawashima E., Yamazaki T. (2010): Application of Cloud Computing to Agriculture and Prospects in Other Fields, Fujitsu Science Technology Journal, Vol. 46. No. 4. 446-464 p.p. 
KSH (Központi Statisztikai Hivatal) 2011. szeptember, Az IKT-eszközök és használatuk a háztartásokban, 2010

Ntaliani M., Costopoulou C., Karetsos S., Tambouris E., Tarabanis K. (2010): Agricultural e-government services: An implementation framework and case study, Computers and Electronics in Agriculture No70 337347 p.p.

OECD Communications Outlook 2011, ISBN 978-92-64-098374, OECD

Pierce F.J., Elliott T.V. (2008): Regional and on-farm wireless sensor networks for agricultural systems in Eastern Washington, Computers and electronics in agriculture No 61, 32-43p.p.

Sasvari P. (2011): The Economic Impacts of Information and Communication Technology In The Hungarian Economy, Journal of Applied and Practical Information Technology, Vol. 1, No. 1, 2011

Sideridis A. B., Koukouli M., Antonopoulou E. (2010): ICT and farmers: lessons learned and future developments, Agricultural Informatics (2010) Vol. 1, No. 2, 35-41 p.p.

Soungalo T., Renfa L, Fanzi Z., Waita H.,N. (2012): Performance Analysis of Interworking between WLAN and 3G Networks Based on Three Approaches, Procedia Engineering No. 29 (2012) $1126-1132$ pp.

Steinberger G., Rothmund M., Auernhammer H. (2009): Mobile farm equipment as a data source in an agricultural service architecture, Computers and electronics in agriculture No 65, 238-246p.

TEIR (Országos Területfejlesztési és Területrendezési Információs Rendszer) 2012 teir.vati.hu

The World Bank, 2011 : ICT in Agriculture Connecting Smallholders to Knowledge, Networks, and Institutions, Report Number 64605

Voulodimos A.S., Patrikakis C.Z., Sideridis A.B., Ntafis V.A., Xylouri E.M. (2010): A complete farm management system based on animal identification using RFID technology Computers and Electronics in Agriculture No 70, 380-388 p.p. 